\title{
INDICATORS OF FINANCIAL SYSTEM STABILITY: \\ TOWARDS AN AGGREGATE FINANCIAL STABILITY \\ INDICATOR?
}

\author{
Adam Geršl, Jaroslav Heřmánek*
}

\begin{abstract}
:
This article sets out to describe and discuss the methodology of selected financial soundness and financial stability indicators, including the attempts to construct an aggregate financial stability indicator. The first part is devoted to discussion of Financial Stability Indicators by the International Monetary Fund and presents also the values of the IMF's core Financial Soundness Indicators for the Czech Republic and other selected countries, using the data from the 2005 pilot study. This part partly covers also other existing approaches to definition and collection of partial financial soundness indicators, such as the indicators regularly assessed by the European Central Bank. In the second part, the article reviews existing approaches to construct an aggregate financial stability indicator. These include alternative approaches using balance sheet and profit and loss data, as well as financial market and regulatory agencies' data. The last part constructs a preliminary composite indicator for the stability of the Czech banking system and discusses its development over time.
\end{abstract}

Keywords: financial stability; banking system; aggregation

JEL Classification: G21, C43

\section{Introduction}

In response to the global financial crises in the 1980 s and 1990 s, national and international institutions started to monitor the soundness of the financial system more intensively. A wide range of instruments is used to assess financial system stability

* Adam Geršl, Czech National Bank, Prague, and Institute of Economic Studies, Charles University in Prague (adam.gers1@cnb.cz); Jaroslav Heřmánek, Czech National Bank, Prague (jaroslav.hermanek@cnb.cz).

The authors wish to thank Jan Frait, Michal Hlaváček, Tomáš Holub, Eva Komárková, Kateřina Šmídková and two anonymous referees for helpful comments. The article was supported by the Czech Ministry of Education Grant MSMT 0021620841 and presented at the CCBS/NBP regional workshop on financial stability, Warsaw, 10-12 October 2007. The findings, interpretations and conclusions expressed in this paper are entirely those of the authors and do not represent the views of any of the above-mentioned institutions. 
in analytical practice. These include in particular analysis of quantitative indicators of financial system soundness and stability, including stress testing. These indicators strive to cover the issue of financial stability as a systemic phenomenon and therefore concern not only financial institutions and markets, but also the real and government sectors as the main debtors of financial institutions, and also the financial infrastructure (IMF and WB 2005).

Unlike price stability, financial stability has neither an established definition nor an aggregate indicator that the central bank can use as a measure of financial instability. Whereas at least some consensus has been reached on the definition of financial stability, the construction of an aggregate financial stability indicator is still in the research and experimental phase.

This article discusses the financial soundness indicators used (Sections 2 and 3) and some of the existing efforts to construct an aggregate financial stability indicator (Section 4). Based on the international experience, an aggregate financial stability indicator is then experimentally compiled for the Czech Republic, focusing on the stability of the banking sector (Section 5). As most of the indicators relate primarily to banks (deposit takers) as key institutions in the financial system, the quantitative assessment of financial stability concentrates on indicators of the soundness of the banking sector. At the same time, however, most of the indicators do not take into account current degree of interrelationships in today's globalized financial markets and thus the risk of contagion from foreign financial markets. Some of the risks for financial stability related to cross-border financing and foreign ownership of key financial institutions are covered elsewhere (Geršl 2007) and are not subject of this article.

Most of the indicators are not able to capture current depth of financial markets, including the development of complicated financial structured instruments and products. Nor are they able to take into account possible interrelationship within the financial systems themselves and several key risks, such as counterparty risk in capital and derivatives markets. As the summer 2007 credit crisis showed, traditional indicators of banks' soundness might not be appropriate to predict some key risks with serious consequences to profitability and solvency of financial institutions. One of the reasons is that some of the key risks were kept as off-balance sheet items. Thus, the indicators discussed further below must be interpreted with caution having in mind their only partial coverage of today's complicated financial system.

\section{IMF Financial Soundness Indicators and ECB Macro-prudential Indicators}

The objective of the set of financial stability indicators is to provide users with a rough idea of the soundness of the financial sector as a whole. It would be ideal, of course, if these indicators were comparable at the international level. To achieve this objective, in 1999 the International Monetary Fund (IMF) in co-operation with national authorities launched an initiative focused on formulating a definition and single methodology for the compilation of Financial Soundness Indicators (FSIs). ${ }^{1}$ This initiative resulted in the

1 In the same time, the Financial Sector Assessment Program (FSAP) - a joint IMF/WB program focused on the assessment of the soundness and development of the financial sector - was launched. 
creation of a Compilation Guide on Financial Soundness Indicators, which was discussed in detail in 2002 and 2003 and the final version of which was published in March 2006 (IMF 2006).

Table 1

Core IMF Financial Soundness Indicators for Deposit Takers

\begin{tabular}{|l|l|}
\hline Category & \multicolumn{1}{|c|}{ Indicator } \\
\hline Capital adequacy & $\begin{array}{l}\text { Regulatory capital to risk-weighted assets } \\
\text { Regulatory Tier I capital to risk-weighted assets } \\
\text { Non-performing loans net of provisions to capital }\end{array}$ \\
\hline Asset quality & $\begin{array}{l}\text { Non-performing loans to total gross loans } \\
\text { Sectoral distribution of loans to total loans }\end{array}$ \\
\hline Earnings and profitability & $\begin{array}{l}\text { Return on assets } \\
\text { Return on equity } \\
\text { Interest margin to gross income } \\
\text { Non-interest expenses to gross income }\end{array}$ \\
\hline Liquidity & $\begin{array}{l}\text { Liquid assets to total assets } \\
\text { Liquid assets to short-term liabilities }\end{array}$ \\
\hline Exposure to FX risk & Net open position in foreign exchange to capital \\
\hline
\end{tabular}

Source: Compilation Guide for Financial Soundness Indicators (IMF 2006).

The total of 39 FSIs are divided into two groups. The first group consists of the main indicators (the core set) relating to the banking sector (12 indicators, see Table 1). The core FSIs relate to five basic areas relevant from the point of view of banking business and are compatible with the so-called CAMELS methodology for the assessment of the soundness of individual financial institutions (Capital adequacy, Asset quality, Management soundness, Earnings, Liquidity, Sensitivity to market risk). ${ }^{2}$ The capital adequacy indicators measure the banking sector's ability to absorb sudden losses and are thus closest to the "resilience to shocks" concept, whereas the asset quality indicators are directly associated with potential risks to banks' solvency. The profitability indicators measure the ability to absorb losses without any impact on capital, while the liquidity indicators measure banks' resilience to cash flow shocks. Foreign currency exposure is an indicator measuring a bank's risk exposure with regard to movements in asset prices on financial markets. The management quality indicators were ultimately not included in the FSIs owing to difficulties connected with quantifying indicators that are qualitative in nature (Sundararajan et al. 2002).

The remaining 27 indicators belong to the second group (the encouraged set), which includes some other banking sector indicators, but also indicators from non-bank financial institutions, non-financial corporations, households, financial markets and property markets (see Table 2 ). The inclusion of non-banking sector indicators in the FSIs reflects the interconnection of the financial and real sectors,

2 For a discussion of the FSIs within the CAMELS methodology, see, for example, Evans et al. (2000), Sundararajan et al. (2002) and IMF and WB (2005). 
as, for example, unfavourable developments in the corporate sector pass through to the loan portfolio of banks and may thus have a negative effect on financial stability. ${ }^{3}$

\section{Table 2}

\section{Encouraged IMF Financial Soundness Indicators}

\begin{tabular}{|c|c|}
\hline Category & Indicator \\
\hline Deposit Takers (DTs) & $\begin{array}{l}\text { Capital to assets } \\
\text { Large exposures } \\
\text { (i) total number of large exposures } \\
\text { (ii) total exposure of } 5 \text { largest DTs to } 5 \text { largest resident entities to capital } \\
\text { (iii) total exposures of DTs to affil. entities \& connected parties to capital } \\
\text { Geographical distribution of loans to total loans } \\
\text { Gross asset position in financial derivatives to capital } \\
\text { Gross liability position in financial derivatives to capital } \\
\text { Trading income to total income } \\
\text { Personnel expenses to noninterest expenses } \\
\text { Spread between reference lending and deposit rates (in basis points) } \\
\text { Spread between highest and lowest interbank rate (in basis points) } \\
\text { Customer deposits to total (non-interbank) loans } \\
\text { Foreign currency-denominated loans to total loans } \\
\text { Foreign currency-denominated liabilities to total liabilities } \\
\text { Net open position in equities to capital }\end{array}$ \\
\hline $\begin{array}{l}\text { Other Financial } \\
\text { Corporations (OFCs) }\end{array}$ & $\begin{array}{l}\text { OFCs assets to total financial system assets } \\
\text { OFCs assets to Gross Domestic Product (GDP) }\end{array}$ \\
\hline $\begin{array}{l}\text { Nonfinancial } \\
\text { Corporations (NFCs) }\end{array}$ & $\begin{array}{l}\text { Total debt to equity } \\
\text { Return on equity } \\
\text { Earnings to interest and principal expenses } \\
\text { Net foreign exchange exposure to equity } \\
\text { Number of applications for protection from creditors }\end{array}$ \\
\hline Households (HHs) & $\begin{array}{l}\text { Household debt to GDP } \\
\text { Household debt service and principal payments to income }\end{array}$ \\
\hline Market Liquidity & $\begin{array}{l}\text { Average bid-ask spread in the securities market (percentage of mid-point price) }{ }^{1)} \\
\text { Average daily turnover ratio in the securities market }{ }^{1)}\end{array}$ \\
\hline Real Estate Markets & $\begin{array}{l}\text { Residential real estate prices (annual percentage increase) } \\
\text { Commercial real estate prices (annual percentage increase) } \\
\text { Residential real estate loans to total loans } \\
\text { Commercial real estate loans to total loans }\end{array}$ \\
\hline
\end{tabular}

1) Or in other markets that are most relevant to bank liquidity, such as foreign exchange markets. Source: Compilation Guide for Financial Soundness Indicators (IMF 2006).

3 Within the FSAP the IMF and the World Bank use far more indicators of financial soundness, stability and structure, see IMF and WB (2005). The FSIs thus represent just a selection of the most important indicators in order to cover the largest possible number of countries (this is why, for example, some market indicators are missing, since they are not available in numerous countries). 
The main goal of the FSIs is international comparability, which should be guaranteed by the fact that all countries publishing FSIs will use the same methodology. International comparability is, however, still limited by some differences at national level, particularly in accounting standards but also in the data collection formats needed for calculating the FSIs. ${ }^{4}$

In parallel with the work on the FSIs, in 1999 the European System of Central Banks (ESCB) launched a project to prepare an EU Banking Sector Stability Report (ECB 2006a). To this end, the European Central Bank (ECB) in co-operation with national central banks and banking supervisors started working on a methodology for and collection of the so-called macro-prudential indicators (MPIs) for monitoring the financial soundness of the banking sector. ${ }^{5}$ The motive, i.e. to identify risky developments in the financial sector, and especially the banking sector, is similar as in the case of the IMF Financial Soundness Indicators. There are, however, two major differences. First, the set of MPIs contains far more indicators (in total more than 150). It is clear from the overview of the areas and categories monitored that the MPIs try to identify and measure quite a large number of factors affecting the financial soundness of the European banking sector (see Mörttinen et al. 2005, pp. 22-24).

Second, within the ESCB most bank-related MPIs are compiled and published on a consolidated basis, i.e. the indicators for banks in one country also include their branches and subsidiaries in other EU countries, as well as other financial institutions controlled by them. This concept allows aggregate data to be constructed for the EU as a whole and thus provides a view of the banking system in the European context. However, it leads to some loss of the link between economic developments based on the territorial principle and the evolution of the MPIs published for the "purely domestic" banking sector in countries where foreign banks from the EU are heavily represented (e.g. new Member States, including the Czech Republic). ${ }^{6}$

A comparison of the structure of the IMF and ECB indicators reveals that they overlap. Nonetheless, they display some methodological differences (e.g. as regards consolidation) and overlap only partially or differ in terms of the coverage of the data monitored. Although the MPI set includes far more indicators than the FSI set, Mörttinen et al. (2005, pp. 54-57) demonstrate that some FSIs (particularly in the set of encouraged indicators) have no equivalent MPIs within the ESCB. When monitoring financial stability, it is therefore appropriate to combine the two sets of relevant indicators.

4 Deviations from the recommended IMF methodology also exist in advanced countries; see Deutsche Bundesbank (2006).

5 For a detailed discussion of the MPIs see Mörttinen et al. (2005). In addition to the MPIs, which are used to monitor financial system soundness and stability, the ESCB compiles structural indicators for monitoring EU banking sector developments; see ECB (2006b).

6 The IMF Financial Soundness Indicators are also compiled on a consolidated basis; see IMF (2006). Nonetheless, the Compilation Guide offers several possible types of consolidation when compiling FSIs, including on an unconsolidated basis on the territorial principle (i.e. including foreign-controlled banks operating in the domestic market). 
The method of assessing the financial or banking stability indicators is a separate question. Although for some indicators there exist certain "optimal" values, which are even anchored in national regulations (e.g. a threshold of $8 \%$ for capital adequacy, a value close to zero for net open positions in foreign exchange), many other indicators have no such absolute "benchmarks". The assessment should thus focus on the evolution of indicators over time and on comparisons with other countries.

The FSIs may, however, be used in stress testing. ${ }^{7}$ A big advantage of stress tests is that they provide a link between individual FSIs and, unlike the indicators, which are relatively static in nature, also allow us to take into account the potential losses that the financial sector would suffer in the event of a shock (Craig and Sundararajan 2003). The results of regular stress testing, especially of the banking sector, may thus also serve as an additional financial soundness indicator. Another area where stress testing offers substantial value added compared to the monitoring of simple indicators is the analysis of the systemic risk associated with interbank contagion.

\section{IMF Financial Soundness Indicators for the Czech Republic and Selected Countries}

In 2004, the project to prepare a single methodology for the IMF Financial Soundness Indicators was supplemented with a FSI compilation pilot project in some 60 countries (Coordinated Compilation Exercise). The results of this exercise, including the values of individual indicators at the end of 2005 and the metadata, i.e. the statistical methodology, were published by the IMF in January 2007. The Czech Republic took part in this pilot study.

The set of FSIs published allows us to make quite a reliable comparison of banking sector FSIs across countries, despite some methodological differences and slight discrepancies due to national limitations as regards data collection. Table 3 presents the core set of FSIs, i.e. banking sector indicators, for the Czech Republic as compared to other Central European countries in $2005 .^{8}$

Although the comparison of the data across individual Central European countries is complicated by rather different data consolidation methods used for the calculation of the indicators (most of the Czech data are on a consolidated basis, whereas the underlying data for the other countries are not subject to cross-border or cross-sector consolidation), some assessment of the indicators is possible. This is confirmed by the relatively similar values of some indicators available for the Czech Republic on both

7 For the stress testing methodology see Čihák (2004a, 2004b), for application on the Czech banking sector see CNB (2004, 2006a).

8 For simplicity we present here the results for the core FSIs only. The IMF website, however, also provides data for some encouraged indicators; see http://www.imf.org. Large files describing the metadata, i.e. the methodology for the construction of the individual indicators, were also disclosed. 
Table 3

The IMF Core Financial Soundness Indicators for Central European Countries (in \%, 2005)

\begin{tabular}{|l|l|r|r|r|r|r|}
\hline & & $\mathbf{C Z}$ & HU & PL & SK & SI \\
\hline \multirow{2}{*}{$\begin{array}{l}\text { Capital } \\
\text { adequacy }\end{array}$} & Regulatory capital to risk-weighted assets & $11.6(11.9)$ & 11.9 & 14.6 & 12.3 & 10.5 \\
\cline { 2 - 7 } & Regulatory Tier I capital to risk-weighted assets & $11.1(9.4)$ & 11.8 & 14.4 & 13.1 & 8.9 \\
\hline \multirow{4}{*}{$\begin{array}{l}\text { Asset } \\
\text { quality }\end{array}$} & Non-performing loans net of provisions to capital & 12.5 & 5.6 & 11.8 & 6.4 & 5.4 \\
\cline { 2 - 7 } & Non-performing loans to total gross loans & 2.8 & 2.2 & 4.8 & 5.0 & 3.0 \\
\cline { 2 - 7 } & Sectoral distribution of loans to total loans & $\ldots$ & $\ldots$ & $\ldots$ & $\ldots$ & $\ldots$ \\
\hline \multirow{2}{*}{$\begin{array}{l}\text { Earnings } \\
\text { and } \\
\text { profita- } \\
\text { bility }\end{array}$} & Return on assets & $1.7(1.4)$ & 2.1 & 1.6 & 1.1 & 1.0 \\
\cline { 2 - 7 } & Return on equity & $32.1(25.2)$ & 27.0 & 20.6 & 13.7 & 13.5 \\
\hline & Interest margin to gross income & 51.8 & 61.6 & 57.7 & 65.4 & 52.9 \\
\hline \multirow{2}{*}{\begin{tabular}{l} 
Liquidity \\
\cline { 2 - 7 }
\end{tabular}} & Non-interest expenses to gross income & 50.1 & 58.7 & 72.3 & 69.1 & 62.4 \\
\hline & Liquid assets to total assets & 32.1 & 19.7 & 19.9 & 33.5 & 4.8 \\
\hline \multirow{2}{*}{$\begin{array}{l}\text { Exposure } \\
\text { to FX risk }\end{array}$} & Net open position in foreign exchange to capital & -0.1 & -22.8 & 2.5 & -49.1 & 21.8 \\
\hline
\end{tabular}

Note: The data for individual countries are not entirely comparable owing to a different base. For the Czech Republic most of the data is on a consolidated basis (including affiliated domestic financial corporations and foreign branches and subsidiaries), except for asset quality and exposure to FX risk, which are on a solo basis. For the other countries the data are on a solo basis (excluding domestic and foreign subsidiaries). The CZ data in parenthesis are CNB data for banks in the Czech Republic on a solo basis.

Source: IMF, CNB.

a consolidated and unconsolidated (solo) basis (see Table 3). ${ }^{9}$ Table 3 shows that for some indicators (capital adequacy, non-performing loans to total gross loans, liquid assets to total assets) the Czech Republic was ranked roughly in the middle in 2005, whereas for others its position was extreme (a higher share of net non-performing loans in regulatory capital $v s$. high return on equity).

The indicator of coverage of short-term liabilities by liquid assets recorded high values in 2005, due to the still high excess liquidity in the Czech banking sector. Most of the excess liquidity, which is a heritage of a long period of fixed exchange rate regime and then sterilization operations of the central bank in a situation of large capital inflows, is absorbed by the central bank via regular repo operations. In 2005, banks in the Czech Republic also showed a very low net open position (in absolute terms) in foreign exchange $(\mathrm{FX})^{10}$, which probably reflects their lower involvement in foreign exchange trading compared to banks in Hungary or Slovakia. ${ }^{11}$ The high value for Slovakia might be a consequence of a different consolidation of data, but also the relatively

9 However, the other comparisons use the official FSI figures published on the IMF website.

10 Net open position in FX is positive if a bank has more FX assets than FX liabilities.

11 In 2005, according to the FSIs, the share of foreign currency-denominated loans in total loans was roughly $25 \%$ in the Czech Republic, compared to almost 30\% in Slovakia and more than $45 \%$ in Hungary. Similar proportions are apparent when comparing the share of foreign currency-denominated liabilities in total liabilities of banks. The high proportion of foreign currency-denominated loans in Hungary is due largely to a high interest rate differential between the domestic currency and the euro or Swiss franc, in which a relatively large number of loans are denominated in Hungary. 
high relevance of a number of foreign banks with foreign currency liabilities and Slovak koruna assets (often also deposited at the central bank via repo operations). The high number for Slovakia partly reflects also the off-balance sheet FX derivatives and guarantees. On the other hand, the relatively high negative FX open position in Hungary is a consequence of a large external financing of domestic credit growth, given the relatively low deposit base in comparison to other Central European countries. The Czech Republic also recorded the lowest values among the five Central European countries for the ratios of interest margin and non-interest expenses to gross income. ${ }^{12}$ This indicates that in 2005 banks in the Czech Republic relied more on non-interest income for profit generation than banks in the other countries. At the same time, however, they succeeded in curbing their administrative expenses. The differences in the ratio of non-performing loans to total loans among countries are not that large and to some extent might also reflect different classification schemes (traditionally, Poland has much stricter rules for a loan to stay performing).

However, the interpretation of all cross-country differences is hampered, in addition to different data consolidation, by a different methodology used for compiling some of the indicators (in the case of the Czech Republic, for instance, the liquidity indicators do not take into account some short-term deposits on both the assets and liabilities sides).

Given the different results of the individual countries for various indicators, it is not easy to make an overall evaluation of the financial soundness of the banking sector. One of the methods allowing us to compare the financial soundness of the banking sector in a simplified way on the basis of several indicators is to determine the ranking of the individual countries for the individual indicators and then somehow aggregate this ranking for the individual countries. According to this method, each country is assigned a ranking for each indicator based on the comparison (so, using Table 3 as an example, in the case of return on assets, the Czech Republic would be assigned a ranking of 2 and Hungary 1) and the individual rankings for the various indicators are then summed for each country. The country with the lowest total is then assessed as the best and is assigned an overall ranking of 1 . A disadvantage of this non-parametric method is that minimal differences between values have the same weight as big differences. ${ }^{13}$

In addition, this simple method is rather mechanical and the assessment of the individual countries is heavily dependent on the total sample of countries.

Table 4 shows the results of this method, assigning rankings to the Czech Republic, the other Central European countries and some other EU countries. To construct the final ranking we used a sample of all available EU countries (excluding Denmark and Finland, which did not participate in the pilot project, i.e. 25 countries including Bulgaria and Romania) and the core FSIs excluding interest margin to gross income and the sectoral distribution of loans, whose effect on financial stability cannot be simply assessed. A linear approach (i.e. the more - or for some indicators the less - the better) was applied for the other indicators, except for net open position in foreign exchange, where we took the absolute distance from the balanced position (i.e. from zero).

12 Gross income is defined as interest margin plus non-interest income.

13 An alternative, possibly more robust method would be to determine the ranking on the basis of quantiles of the individual indicators. 
The results show that compared to the other EU countries the Czech Republic was placed quite well in the overall assessment of the financial soundness of the banking sector in 2005 . The results must be interpreted with caution, however, mainly because of the different consolidation of the underlying data used in calculating the indicators for the individual countries. ${ }^{14}$

Table 4

Rankings of EU Countries according to the IMF's Core Financial Soundness Indicators (2005; rankings among 25 countries; $\min 1$; $\max 25$ )

\begin{tabular}{|l|l|r|r|r|r|r|r|c|}
\hline \multirow{2}{*}{$\begin{array}{l}\text { Capital } \\
\text { adequacy }\end{array}$} & CZ & HU & PL & SK & SI & AT & DE \\
\hline \multirow{4}{*}{ Asset quality } & $\begin{array}{l}\text { Regulatory capital to risk-weighted assets } \\
\text { assets }\end{array}$ & 17 & 15 & 5 & 13 & 21 & 16 & 14 \\
\hline & $\begin{array}{l}\text { Non-performing loans net of provisions to } \\
\text { capital }\end{array}$ & 17 & 10 & 16 & 12 & 9 & 19 & 23 \\
\cline { 2 - 9 } & Non-performing loans to total gross loans & 15 & 11 & 20 & 21 & 16 & 13 & 19 \\
\hline \multirow{2}{*}{$\begin{array}{l}\text { Earnings and } \\
\text { profitability }\end{array}$} & Return on assets & 6 & 1 & 7 & 11 & 12 & 21 & 25 \\
\cline { 2 - 8 } & Return on equity & 1 & 2 & 7 & 22 & 23 & 18 & 21 \\
\hline \multirow{2}{*}{ Liquidity } & Non-interest expenses to gross income & 3 & 14 & 24 & 21 & 17 & 23 & 16 \\
\hline & Liquid assets to total assets & 10 & 21 & 20 & 9 & 24 & 14 & 3 \\
\hline $\begin{array}{l}\text { Exposure to } \\
\text { FX risk }\end{array}$ & $\begin{array}{l}\text { Net open position in foreign exchange to } \\
\text { capital }\end{array}$ & 1 & 21 & 7 & 22 & 20 & 10 & 17 \\
\hline $\begin{array}{l}\text { Overall } \\
\text { ranking }\end{array}$ & $\begin{array}{l}\text { Ranking of sum of rankings for individual } \\
\text { indicators }\end{array}$ & 4 & 12 & 13 & 19 & 24 & 21 & 23 \\
\hline
\end{tabular}

Note: The number indicates the ranking among the $25 \mathrm{EU}$ countries, i.e. a lower number means a better result. Source: IMF, authors' calculations.

The difference in ranking between the new and original EU member countries may reflect a different level of financial intermediation and illustrate some trade-off between financial sector stability and financial sector development (Hlaváček, 2007). The banking sectors in the new member countries are dominated by foreign-owned banks with sufficient capital, minimal bad assets (which were cleared out from banks' balance sheets prior to their privatisation), high liquidity and a prudential approach to the financing of post-transition economies. This contrasts with the banks in the original EU member countries, with high exposures to the real economy and deep financial intermediation in all sectors, to the detriment of capital adequacy and liquidity. The difference between these two groups' results may also be due to a different level of risk. This motivates banks operating in post-transition countries to maintain a certain capital and liquidity cushion, contributing to better results in the assessment of financial soundness.

14 The Czech Republic has particularly good results in net open position in foreign exchange and return on equity. For a more detailed discussion of these two indicators in 2005, see CNB (2006a, 2006b). 


\section{Attempts to Construct an Aggregate Financial Stability Indicator}

Some central bank publications have recently attempted to construct a single indicator to indicate the level of stability of the financial system in the country concerned. This is a very tough task given the complex nature of the financial system and the existence of numerous links between financial market participants, non-financial sectors and financial institutions. The attempts to date can therefore be viewed as preliminary testing of alternative approaches to the construction of this indicator, not as consensual standards at the international level as is the case for the FSIs and MPIs. ${ }^{15}$ Most of the attempts focus on constructing an aggregate indicator for the banking sector, which is the most important part of the financial system with respect to financial stability.

A relatively simple aggregate indicator of banking sector stability can be constructed as a weighted average of partial indicators of the financial soundness of banks. Such an index is used, for example, by the Turkish central bank (CBRT, 2006). Its financial strength index consists of six sub-indices covering asset quality, liquidity, foreign exchange risk, interest rate risk, profitability and capital adequacy. Before aggregation the individual sub-indices are normalised in order to achieve the same variance (variance-equal weighting scheme).

An alternative method is to construct an aggregate financial soundness indicator using daily data from the financial markets (such as prices of banking shares and other financial assets). The reason is that such data can signal any difficulties in the financial sector in advance, as indicated by market perceptions about their probability. The financial fragility indicator presented by experts from the US Federal Reserve System (Nelson and Perli 2005) and the financial stress index calculated by experts of the Canadian central bank (Illing and Liu 2003) are examples of such an approach.

A sensible approach is to combine information from the financial markets with information from the financial statements of financial institutions. This approach has been adopted, for example, by the Swiss central bank in the construction of a "stress index" for the banking sector (SNB, 2006). Along with indicators derived from banks' balance sheets and performance (change in profitability, capital, asset quality and the number of bank branches), this approach thus also uses market indicators (change in prices of banking shares and bonds) and other indicators, such as interbank exposure and additional supervisory information (the share of bank assets in the regulator's "watch list").

Experts from the Netherlands central bank have opted for quite an original approach to the construction of the index (van den End 2006). The financial stability conditions index is constructed on the basis of an enlarged monetary conditions index and thus contains interest rates, the effective exchange rate, real estate and stock prices, the solvency of financial institutions and volatility of the stock index of financial institutions. An innovation in this index is, however, the introduction of upper and lower critical limits to take account of potential non-linear effects. Too low an index value means increased instability, whereas too high a value may result in the accumulation of financial imbalances, since very positive developments and minimal market volatility may lead to distortion of relative prices, inefficient fund allocation and lower prudence and risk limits.

15 The use of an aggregate indicator for financial stability assessment is criticised, for example, by Schinasi (2006, pp. 89, 125-126). 
Therefore, the ideal evolution of the index is one within a particular financial stability band.

A new approach to the construction of an aggregate financial stability indicator consists in calculating default risk at the level of the entire financial system, or its main sectors, for instance using the Merton model (Van den End and Tabbae, 2005). ${ }^{16}$ A similar systemic risk indicator based on the stochastic default risk distribution of individual institutions as an operational financial stability indicator is proposed, for example, by Čihák (2007). The advantage of these indicators lies in their close linkage with problems in the financial sector (default of major financial institutions or a sector) and with the business cycle. The disadvantages include, however, demanding analysis and in some cases also the existence of a liquid stock market with a good representative sample of individual sectors.

\section{The Choice of a Banking Stability Index for the Czech Republic}

On the basis of the debate above we try to construct experimentally a simple aggregate banking sector stability index and to discuss its advantages and disadvantages. The use of market indicators in the case of the Czech Republic runs into the problems of a limited number of listed banks, a minimal number of listed bank bonds and a relatively shallow capital market in general. To construct the index, labelled the banking stability index, we thus use the traditional ratio indicators only.

Table 5

Partial Indicators Included in the Banking Stability Index

\begin{tabular}{|c|c|c|c|c|}
\hline Partial indicator & $\begin{array}{c}\text { Weight in } \\
\text { index }\end{array}$ & Adjustments & Variables & Impact \\
\hline Capital adequacy & 0.05 & Normalisation & Capital adequacy (\%) & + \\
\hline Asset quality & 0.25 & Normalisation & Non-performing loans/total loans (\%) & - \\
\hline \multirow{2}{*}{ Profitability } & \multirow{2}{*}{0.25} & \multirow{2}{*}{$\begin{array}{l}\text { Mean of normalised } \\
\text { values }\end{array}$} & Return on assets $(\%)$ & \multirow{2}{*}{+} \\
\hline & & & Return on equity (\%) & \\
\hline \multirow{2}{*}{ Liquidity } & \multirow{2}{*}{0.25} & \multirow{2}{*}{$\begin{array}{l}\text { Mean of normalised } \\
\text { values }\end{array}$} & Quick assets/assets (\%) & \multirow{2}{*}{+} \\
\hline & & & Quick assets/client deposits (\%) & \\
\hline Interest rate risk & 0.1 & Normalisation & $\begin{array}{l}\text { Cumulative net balance sheet position } \\
\text { to } 3 \text { months/assets }(\%)\end{array}$ & + \\
\hline \multirow{2}{*}{$\begin{array}{l}\text { Foreign exchange } \\
\text { risk }\end{array}$} & \multirow[b]{2}{*}{0.1} & \multirow{2}{*}{$\begin{array}{l}\text { Mean of normalised } \\
\text { values }\end{array}$} & $\begin{array}{l}\text { Absolute value of open total position } \\
\text { in foreign exchange/Tier } 1 \text { capital (\%) }\end{array}$ & \multirow[b]{2}{*}{ - } \\
\hline & & & $\begin{array}{l}\text { Absolute value of open balance sheet } \\
\text { position in foreign exchange/Tier } 1 \\
\text { capital }(\%)\end{array}$ & \\
\hline
\end{tabular}

Table 5 shows the partial indicators that were chosen for the construction of the aggregate index, including their weights. The selection of the individual partial indicators was governed by current international practice. Capital adequacy and profitability indicate the cushion which a bank has at its disposal against potential risks. Asset quality

16 See also Jakubík (2007). 
evaluates the degree of credit risk. Liquidity measures a bank's reserve against potential liquidity problems, i.e. a share of very liquid assets (such as short-term bank deposits, cash or liquid government notes) that could be sold to cover the demand in case of a sudden withdrawal of deposits. Interest rate risk measures the time mismatch between assets and liabilities and indirectly measures the potential losses caused by a potential rise in interest rates. ${ }^{17}$ The calculation takes into account also whether assets or liabilities have floating coupon in case of bonds. Foreign exchange risk covers banks' exposure to exchange rate movements in both directions, i.e. measures the potential loss in case of a sudden change of currency value. It does not take into account the differences in maturity of FX assets and liabilities, as these are covered in the indicator of interest rate risk. All the partial indicators were normalised before aggregation so that they have the same variance.

The weights of the partial indicators were set by expert judgment and do not take into account the potential correlation between individual partial indicators. The starting point was the assignment of identical weights to all the partial indicators; nonetheless, the weakening of the capital adequacy, interest rate and foreign exchange risk indicators reflects a motivation to consider some specific features of the Czech banking sector. The lowest weight assigned to capital adequacy weakens its effect on the total index due to excessively high values in 2000-2003, which were generated by temporary factors (clear-outs of bad assets from the banking sector, privatisation, necessary capital increases by foreign owners, etc.). These high values artificially increase the average, and the current fall in capital adequacy towards more reasonable figures was thus overvalued with respect to risk growth. Interest rate risk was assigned a lower weight for two reasons: first, the time mismatch between assets and liabilities in terms of short-term liabilities and long-term assets is a typical feature of banking business, and the widening of this mismatch reflects deepening financial intermediation in a post-transition economy. Second, banks successfully manage part of this risk using interest rate derivatives, which are not included in the indicator. The low weight on exchange rate risk reflects the relatively low exposure of banks to this risk and also a lack of reliable data, since data on the total foreign exchange position have been collected only since 2001 .

Chart 1 illustrates the evolution of the partial indicators in 1997-2006. All the indicators were converted so that an increase means an improvement and a decrease means deterioration. A positive value means that an indicator is above its historical average (calculated from 1997-2006) and a negative value means it is below its historical average.

17 In the terminology of the capital adequacy framework (Basel II), this risk is termed interest rate risk in the banking book and is sometimes also referred to as the time mismatch between assets and liabilities (CNB 2006b). This risk arises when a rise in interest rates forces a bank to pay higher interest on the liability side (e.g. remunerated demand deposits or deposits with a short interest rate fixation period) without it being able to charge higher rates on the asset side (e.g. loans with longer fixation periods). This time mismatch in possible refixation leads directly to losses. In addition, there is interest rate risk in the trading book, which expresses the potential losses in the trading portfolio (e.g. bonds and other assets held for trading and sensitive to interest rate changes) caused by movements in market interest rates. 
Chart 1

Partial Indicators of Banking Sector Stability

(in standard deviations from the historical average of 1997-2006)
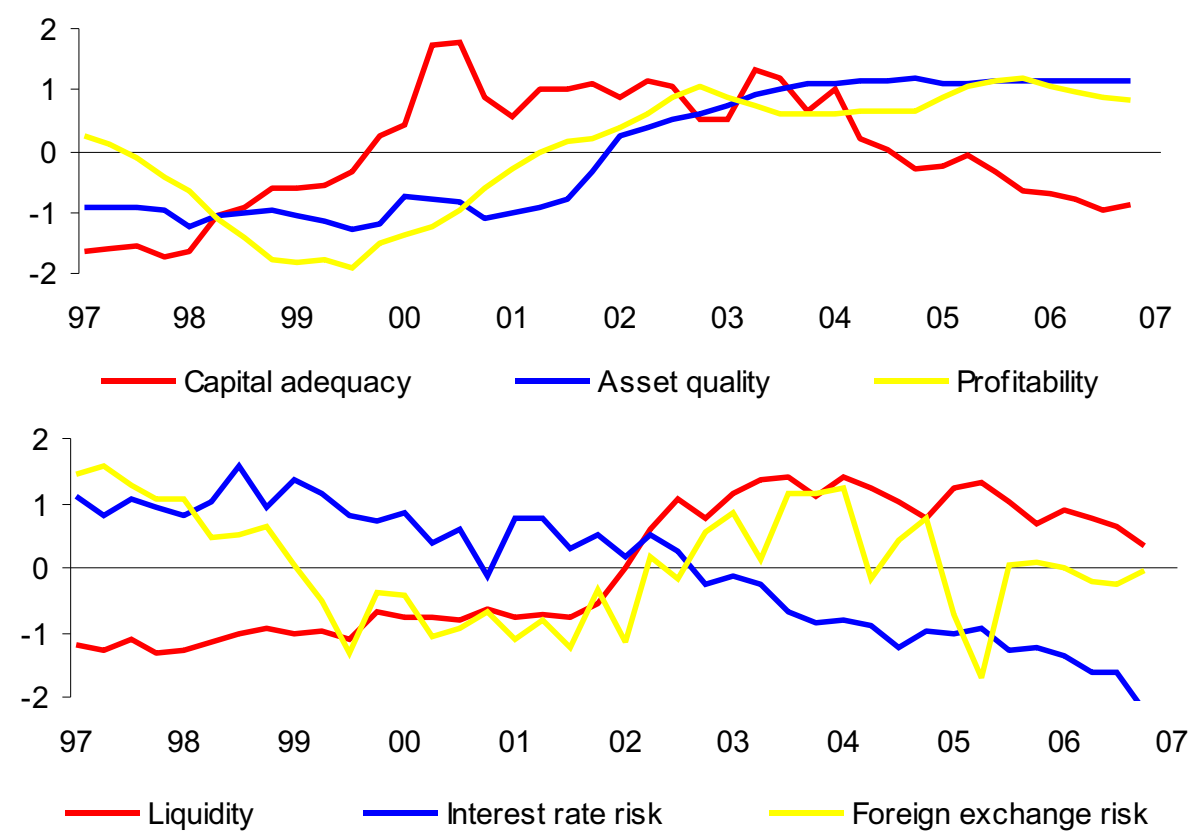

Source:CNB.

The chart indicates that in the last 4-5 years there has been an improvement in asset quality, profitability and liquidity, and, by contrast, some deterioration in capital adequacy and interest rate risk (in terms of a decline in partial indicators). Foreign exchange risk has been rather volatile, but with some interruptions it has moved around the historical average of an essentially balanced foreign exchange position.

Chart 2 shows the evolution of the resulting banking stability index together with the evolution of the economic environment in the Czech Republic, which of course has affected the banking sector. We can identify three basic phases in the evolution of the index. The low and falling index values in 1997-1999 are due to economic problems and a banking crisis in the Czech Republic in the second half of the 1990s. That period was characterised by poor asset quality, low profitability and liquidity of banks and relatively low capital. At the time, the economy was in recession and banks and debtors were adversely affected by high interest rates.

In 1999-2001, there was a modest economic recovery and interest rates fell gradually, which had a positive effect on the economy and on the banking sector. However, the improvement in the index in this period was driven more by structural and institutional changes, since the banking sector was being cleaned up and consolidated, bad assets were being cleared out, and essential ownership changes were being made (privatisation to foreign strategic owners, see Bárta, Geršl and Singer, 2008). Since 2002 the index has been fluctuating in positive values. Another for the improving stability is the favou- 
rable phase of the business cycle, associated with economic growth and low interest rates. Only in this phase is it probably meaningful to interpret developments on the basis of standard financial soundness and stability indicators.

\section{Chart 2}

\section{Banking Stability Index}

(index in standard deviations from the historical average of 1997-2006, GDP growth and Pribor in \%)

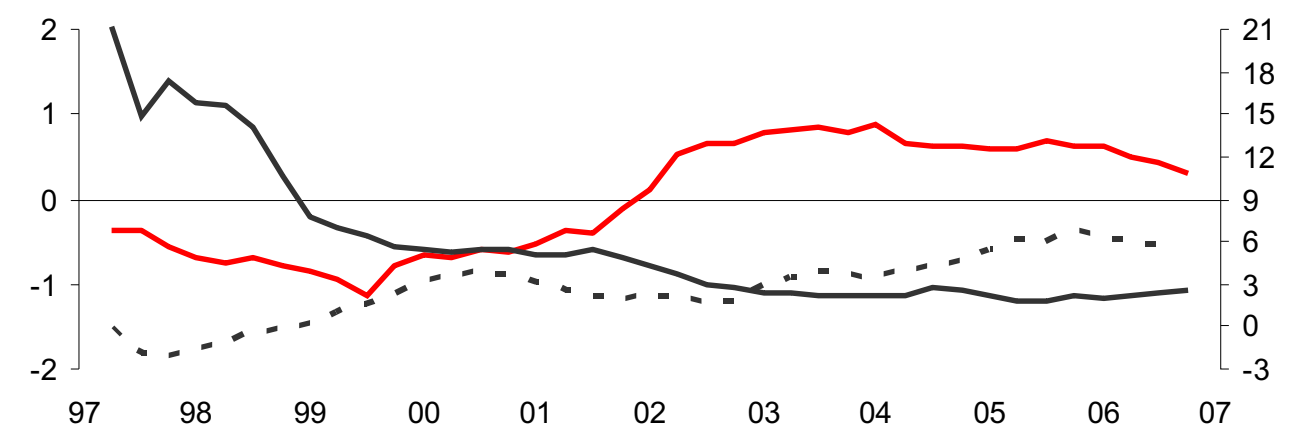

\footnotetext{
— Banking stability index (left-hand scale) - - - - GDP grow th (\%; right-hand scale) 3M Pribor (\%; right-hand scale)
}

Source: CNB, author's calculation.

The slight fall in the banking stability index recently can be explained by a combination of falling capital adequacy and liquidity and increasing interest rate risk amid unchanged asset quality and profitability. This evolution of the total indicator and the partial indicators is largely due to credit expansion in a situation of low interest rates in recent years. The rise in lending binds more capital to risk-weighted assets, thereby decreasing capital adequacy. This decrease is also due in large part to repatriation of bank earnings in the form of dividends paid to foreign owners. Low real interest rates support growth in long-term loans, but at the same time reduce the opportunity costs of holding money in the form of sight deposits, which leads to a short time position for liabilities, a widening of the time mismatch between assets and liabilities and a rise in interest rate risk.

The decline in the banking stability index can also be interpreted as a return to average values and capital adequacy optimisation in a situation of credit growth. The fall in the index may also reflect a smaller need for "cushions" against potential risks in an environment of increased financial and economic stability.

That said, the present evolution of the banking stability index may signal some risks going forward. Should the credit expansion continue at a similar rate as in the previous three years, banks will be forced to strengthen their capital adequacy and decrease the time mismatch between assets and liabilities, probably using interest rate derivatives and other instruments. In the event of a cooling of economic activity or a rise in interest 
rates, banks may also face more danger from an increase in unpaid loans. Some banks have already started to react to this situation in advance by increasing their capital or changing their profit distribution strategy.

\section{Conclusions}

To assess the stability of the financial system and its most important part, i.e. the banking sector, it is appropriate to use a number of quantitative indicators and combine various approaches, including the calculation of financial soundness indicators, stress testing and some aggregate view of the development of the financial or banking sector based on a simple aggregate indicator.

Financial stability indicators compiled at the level of international institutions, such as the IMF or the ECB, facilitate the assessment of financial soundness and stability in international comparison thanks to their single methodology. Recently published data from an IMF pilot project for the compilation of financial soundness indicators indicate that the Czech banking sector compares quite favourably with the other EU countries.

An aggregate financial stability indicator may serve as a first step towards better operationalising the concept of financial stability and building a more appropriate framework for assessing financial stability. The experimentally compiled banking stability index for the Czech Republic constitutes one of the alternative methods for constructing an aggregate financial stability indicator. Its main advantage is a possibility to compare the banking system soundness as a whole over time and detect possible adverse trends. The discussion of its pros and cons, however, suggests that it cannot simply be used to assess financial stability without knowledge and use of other supporting instruments and indicators. As mentioned in the introduction, the index also does not take into account a number of potential risks related to off-balance sheet investments or cross-border dimension of the banking business. Nonetheless, it may serve as the basis for further efforts to construct quantitative indicators that better reflect the nature of the financial system and its links with the real sector and other countries.

\section{References}

Bárta, V., Geršl, A., Singer, M. (2008), "The Czech Banking Sector after 16 years of Restructuring: Fundamental Changes and Costly Lessons", in Institutional Foundations for Sound Finance. Washington, DC: IMF/WB, forthcoming in 2008.

CBRT (2006), Financial Stability Report. Vol. 2, June. Ankara: Central Bank of the Republic of Turkey.

Craig, R. S., Sundararajan, V. (2003), "Using Financial Soundness Indicators to Assess Risks to Financial Stability”, in Ugolini, P. C., Schaechter, A., Stone, M. R., eds., Challenges to Central Banking from Globalized Financial Systems (Papers presented at the ninth conference on central banking). Washington, DC: IMF.

CNB (2004), Financial Stability Report 2004. Prague: Czech National Bank, December.

CNB (2006a), Financial Stability Report 2005. Prague: Czech National Bank, May.

CNB (2006b), Banking Supervision 2005. Prague: Czech National Bank, June.

Čihák, M. (2004a), "Stress Testing: A Review of Key Concepts". CNB Internal Research and Policy Note, (2).

Čihák, M. (2004b), "Designing Stress Tests for the Czech Banking System”. CNB Internal Research and Policy Note, (3).

Čihák, M. (2007), "Systemic Loss: A Measure of Financial Stability". Czech Journal of Economics and Finance, (1-2), pp. 5-26. 
Deutsche Bundesbank (2006), "Financial Soundness Indicators: A Contribution to Improving the Worldwide Availability of Data for Financial Stability Analysis". Financial Stability Review, November.

Evans, O., Leone, A. M., Gill, M., Hilbers, P. (2000), "Macroprudential Indicators of Financial System Soundness", IMF Occasional Paper No. 192.

ECB (2006a), EU Banking Sector Stability. Frankfurt am Main: European Central Bank, November.

ECB (2006b), EU Banking Structures. Frankfurt am Main: European Central Bank, October.

Geršl, A. (2007), "Foreign Banks, Foreign Lending and Cross-Border Contagion: Evidence from the BIS Data". Czech Journal of Economics and Finance, (1-2), pp. 27-40.

Hlaváček, M. (2007), "Financial Stability Analysis in a Developing Economy". Czech Journal of Economics and Finance, (1-2), pp. 2-4.

Illing, M., Liu, Y. (2003), "An Index of Financial Stress for Canada”. Bank of Canada Working Paper No. 2003-14.

IMF and WB (2005), Financial Sector Assessment: A Handbook. Washington, DC: International Monetary Fund and World Bank, September.

IMF (2006), Financial Soundness Indicators: Compilation Guide. Washington, DC: International Monetary Fund, March.

Jakubík, P. (2007), "Macroeconomic Environment and Credit Risk". Czech Journal of Economics and Finance, (1-2), pp. 60-78.

Mörttinen, L., Poloni, P., Sandras, P., Vesala, J. (2005), "Analysing Banking Sector Conditions: How to use macro-prudential indicators". ECB Occasional Paper No. 26, April.

Nelson, W. R., Perli, R. (2005), "Selected Indicators of Financial Stability. 4th Joint Central Bank Research Conference on 'Risk Measurement and Systemic Risk'". Frankfurt am Main: ECB, November.

Schinasi, G. J. (2006), Safeguarding Financial Stability: Theory and Practice. Washington, DC: International Monetary Fund.

Sundararajan, V., Enoch, C., San José, A., Hilbers, P., Krueger, R., Moretti, M., Slack, G. (2002), "Financial Soundness Indicators: Analytical Aspects and Country Practices". IMF Occasional Paper No. 212.

SNB (2006), Financial Stability Report. Bern: Schweizerische Nationalbank, June.

Van den End, J. W. (2006), "Indicator and Boundaries of Financial Stability". DNB Working Paper No. 97/March.

Van den End, J. W., Tabbae, M. (2005), "Measuring Financial Stability: Applying the MfRisk Model to the Netherlands". DNB Working Paper No. 30/March. 